Review Article

\title{
Cement Types, Composition, Uses and Advantages of Nanocement, Environmental Impact on Cement Production, and Possible Solutions
}

\author{
S. P. Dunuweera $\mathbb{D}^{1,2}$ and R. M. G. Rajapakse $\mathbb{i}^{1,2}$ \\ ${ }^{1}$ Department of Chemistry, Faculty of Science, University of Peradeniya, Peradeniya, Sri Lanka \\ ${ }^{2}$ Postgraduate Institute of Science (PGIS), University of Peradeniya, Peradeniya, Sri Lanka \\ Correspondence should be addressed to R. M. G. Rajapakse; rmgr@pdn.ac.lk
}

Received 29 October 2017; Revised 27 February 2018; Accepted 6 March 2018; Published 4 April 2018

Academic Editor: Julian Wang

Copyright (C) 2018 S. P. Dunuweera and R. M. G. Rajapakse. This is an open access article distributed under the Creative Commons Attribution License, which permits unrestricted use, distribution, and reproduction in any medium, provided the original work is properly cited.

\begin{abstract}
We first discuss cement production and special nomenclature used by cement industrialists in expressing the composition of their cement products. We reveal different types of cement products, their compositions, properties, and typical uses. Wherever possible, we tend to give reasons as to why a particular cement type is more suitable for a given purpose than other types. Cement manufacturing processes are associated with emissions of large quantities of greenhouse gases and environmental pollutants. We give below quantitative and qualitative analyses of environmental impact of cement manufacturing. Controlling pollution is a mandatory legal and social requirement pertinent to any industry. As cement industry is one of the biggest $\mathrm{CO}_{2}$ emitters, it is appropriate to discuss different ways and means of $\mathrm{CO}_{2}$ capture, which will be done next. Finally, we give an account of production of nanocement and advantages associated with nanocement. Nanofillers such as nanotitania, nanosilica, and nanoalumina can be produced in large industrial scale via top-down approach of reducing size of naturally available bulk raw materials to those in the nanorange of $1 \mathrm{~nm}-100 \mathrm{~nm}$. We mention the preparation of nanotitania and nanosilica from Sri Lankan mineral sands and quartz deposits, respectively, for the use as additives in cement products to improve performance and reduce the amount and cost of cement production and consequent environmental impacts. As of now, mineral sands and other treasures of minerals are exported without much value addition. Simple chemical modifications or physical treatments would add enormous value to these natural materials. Sri Lanka is gifted with highly pure quartz and graphite from which silica and graphite nanoparticles, respectively, can be prepared by simple size reduction processes. These can be used as additives in cements. Separation of constituents of mineral sands is already an ongoing process.
\end{abstract}

\section{Introduction}

This paper is an extended version of the Conference Paper published in the Proceedings of the 28th International Symposium on Transport Phenomena, 22-24 September 2017, Peradeniya, Sri Lanka [1]. As described in it, cement is a powdery substance made with calcined lime and clay as major ingredients. Clay used provides silica, alumina, and iron oxide, while calcined lime basically provides calcium oxide. In cement manufacturing, raw materials of cement are obtained by blasting rock quarries by boring the rock and setting off explosives [2]. These fragmented rocks are then transported to the plant and stored separately in silos. They are then delivered, separately, through chutes to crushes where they are then crushed or pounded to chunks of $\sim 1 / 2$ inch-sized particles [3]. Depending on the type of cement being produced, required proportions of the crushed clay, lime stones, and any other required materials are then mixed by a process known as prehomogenization and milled in a vertical steel mill by grinding the material with the pressure exerted through three conical rollers that roll over a turning milling table. Additionally, horizontal mills inside which the 
TABLE 1: Approximate composition of the cement clinker.

\begin{tabular}{|c|c|c|c|}
\hline Compound & Formula & Notation & wt.\% \\
\hline Celite (tricalcium aluminate) & $\begin{array}{c}\mathrm{Ca}_{3} \mathrm{Al}_{2} \mathrm{O}_{6} \\
{\left[3 \mathrm{CaO} \cdot \mathrm{Al}_{2} \mathrm{O}_{3}\right]}\end{array}$ & $\mathrm{C}_{3} \mathrm{~A}$ & 10 \\
\hline Brownmillerite (tetracalcium aluminoferrite) & $\begin{array}{c}\mathrm{Ca}_{4} \mathrm{Al}_{2} \mathrm{Fe}_{2} \mathrm{O}_{10} \\
{\left[4 \mathrm{CaO} \cdot \mathrm{Al}_{2} \mathrm{O}_{3} \cdot \mathrm{Fe}_{2} \mathrm{O}_{3}\right]}\end{array}$ & $\mathrm{C}_{4} \mathrm{AF}$ & 8 \\
\hline Belite (dicalcium silicate) & $\begin{array}{c}\mathrm{Ca}_{2} \mathrm{SiO}_{4} \\
{\left[2 \mathrm{CaO} \cdot \mathrm{SiO}_{2}\right]}\end{array}$ & $\mathrm{C}_{2} \mathrm{~S}$ & 20 \\
\hline Alite (tricalcium silicate) & $\begin{array}{c}\mathrm{Ca}_{3} \mathrm{SiO}_{5} \\
{\left[3 \mathrm{CaO} \cdot \mathrm{SiO}_{2}\right]}\end{array}$ & $\mathrm{C}_{3} \mathrm{~S}$ & 55 \\
\hline Sodium oxide & $\mathrm{Na}_{2} \mathrm{O}$ & $\mathrm{N}$ & $<2$ \\
\hline Potassium oxide & $\mathrm{K}_{2} \mathrm{O}$ & $\mathrm{K}$ & $\leq 2$ \\
\hline Gypsum (calcium sulphate dihydrate) & $\begin{array}{c}\mathrm{CaSO}_{4} \cdot 2 \mathrm{H}_{2} \mathrm{O} \\
{\left[\mathrm{CaO} \cdot \mathrm{SO}_{3} \cdot 2 \mathrm{H}_{2} \mathrm{O}\right]}\end{array}$ & $\mathrm{CSH}_{2}$ & 5 \\
\hline
\end{tabular}

Adapted from [2]; http://www.engr.psu.edu/ce/courses/ce584/concrete/library/construction/curing/Composition\%20of\%20cement.htm.

material is pulverized by means of steel balls are also used. It is then homogenized again and calcined, at $1400^{\circ} \mathrm{C}$, in rotary kilns for the raw material to be transformed to a clinker, which is a small, dark grey nodule $3-4 \mathrm{~cm}$ in diameter. The clinker is discharged from the lower end of the kiln while it is red-hot, cooled by various steps, ground and mixed with small amounts of gypsum and limestone, and very finely ground to produce cement [4].

In the calcination process, in the kiln, at high temperatures, the above oxides react forming more complex compounds [5]. For instance, reaction between $\mathrm{CaCO}_{3}$, $\mathrm{Al}_{3}\left(\mathrm{SiO}_{3}\right)_{2}$, and $\mathrm{Fe}_{2} \mathrm{O}_{3}$ would give a complex mixture of alite, $(\mathrm{CaO})_{3} \mathrm{SiO}_{2}$; belite, $(\mathrm{CaO})_{2} \mathrm{SiO}_{2}$; tricalcium aluminate, $\mathrm{Ca}_{3}\left(\mathrm{Al}_{2} \mathrm{O}_{3}\right)$; and ferrite phase tetracalcium aluminoferrite, $\mathrm{Ca}_{4} \mathrm{Al}_{2} \mathrm{O}_{3} \mathrm{Fe}_{2} \mathrm{O}_{3}$ with the evolution of $\mathrm{CO}_{2}$ gas in the Portland cement clinker [6]. However, there can be many other minor components also since natural clay also contains $\mathrm{Na}, \mathrm{K}$, and so on. In the chemical analysis of cement, its elemental composition is analyzed (e.g., $\mathrm{Ca}, \mathrm{Si}, \mathrm{Al}, \mathrm{Mg}, \mathrm{Fe}$, $\mathrm{Na}, \mathrm{K}$, and S). Then, the composition is calculated in terms of their oxides and is generally expressed as wt.\% of oxides. For simplicity, if we assume that the clinker contains the above four main oxides, they can be simply represented by the Bogue formulae where $\mathrm{CaO}, \mathrm{Al}_{2} \mathrm{O}_{3}, \mathrm{Fe}_{2} \mathrm{O}_{3}$, and $\mathrm{SiO}_{2}$ are denoted as $\mathrm{C}, \mathrm{A}, \mathrm{F}$, and $\mathrm{S}$, respectively [7]. In this notation, alite (tricalcium silicate) $\left[(\mathrm{CaO})_{3} \mathrm{SiO}_{2}\right]$, belite (dicalcium silicate) $\left[(\mathrm{CaO})_{2} \mathrm{SiO}_{2}\right]$, celite (tricalcium aluminate) $\left[\mathrm{Ca}_{3} \mathrm{Al}_{2} \mathrm{O}_{6}=3 \mathrm{CaO} \cdot \mathrm{Al}_{2} \mathrm{O}_{3}\right]$, and brownmillerite (tetracalcium aluminoferrite) $\left[\mathrm{Ca}_{4} \mathrm{Al}_{2} \mathrm{Fe}_{2} \mathrm{O}_{10}=4 \mathrm{CaO} \cdot \mathrm{Al}_{2} \mathrm{O}_{3} \cdot \mathrm{Fe}_{2} \mathrm{O}_{3}\right]$ are represented by $\mathrm{C}_{3} \mathrm{~S}, \mathrm{C}_{2} \mathrm{~S}, \mathrm{C}_{3} \mathrm{~A}$, and $\mathrm{C}_{3} \mathrm{AF}$, respectively. If we analyze the elemental composition of $\mathrm{Ca}, \mathrm{Al}, \mathrm{Fe}$, and $\mathrm{Si}$, usually from X-ray fluorescence spectroscopy, then we express them as wt.\% of their respective oxides. For example, if the experimentally determined clinker composition is $\mathrm{CaO}=65.6 \%, \mathrm{SiO}_{2}=21.5 \%, \mathrm{Al}_{2} \mathrm{O}_{3}=5.2 \%$, and $\mathrm{Fe}_{2} \mathrm{O}_{3}=2.8 \%$, then Bogue calculations would give $\mathrm{C}_{3} \mathrm{~S}=64.7 \%$, $\mathrm{C}_{2} \mathrm{~S}=12.9 \%, \mathrm{C}_{3} \mathrm{~A}=9.0 \%$, and $\mathrm{C}_{4} \mathrm{AF}=8.5 \%$, respectively [8]. However, cement contains water $\left(\mathrm{H}_{2} \mathrm{O}\right)$, sulphate $\left(\mathrm{SO}_{3}\right)$, sodium oxide $\left(\mathrm{Na}_{2} \mathrm{O}\right)$, potassium oxide $\left(\mathrm{K}_{2} \mathrm{O}\right)$, gypsum $\left(\mathrm{CaSO}_{4} \cdot 2 \mathrm{H}_{2} \mathrm{O}\right)$, which are denoted as $\mathrm{H}, \mathrm{S}, \mathrm{N}, \mathrm{K}$, and $\mathrm{CSH}_{2}$, respectively. Note that gypsum (calcium sulphate dihydrate) is considered as $\mathrm{CaO} \cdot \mathrm{SO}_{3} \cdot 2 \mathrm{H}_{2} \mathrm{O}$ and hence its notation is
$\mathrm{CSH}_{2}$. As such, approximate composition of the cement clinker is different from the above values and is depicted in Table 1.

There are several different types of cements of which Portland cement, Siliceous (ASTM C618 Class F) Fly Ash, Calcareous (ASTM C618 Class C) Fly Ash, slag cement, and silica fume are the major types $[9,10]$. They differ from their chemical composition. Table 2 gives the compositions of the above cement types in terms of $\mathrm{SiO}_{2}, \mathrm{Al}_{2} \mathrm{O}_{3}, \mathrm{Fe}_{2} \mathrm{O}_{3}, \mathrm{CaO}$, $\mathrm{MgO}$, and $\mathrm{SO}_{3}$, and the remaining can be other materials such as $\mathrm{Na}_{2} \mathrm{O}$ and $\mathrm{K}_{2} \mathrm{O}$. Note that $\mathrm{SO}_{3}$ stands for oxide of $\mathrm{S}$, where $\mathrm{S}$ is derived from gypsum $\left(\mathrm{CaSO}_{4} \cdot 2 \mathrm{H}_{2} \mathrm{O}\right)$. Given in Table 2 are also important physical properties such as specific surface area (surface area per unit mass, SSA) and specific gravity (SG) of these different types of cements $[11,12]$.

General use of the Portland cement, Siliceous (ASTM C618 Class F) Fly Ash, Calcareous (ASTM C618 Class C) Fly Ash, slag cement, and silica fume in concrete is as primary binder, cement replacement, cement replacement, cement replacement, and property enhancer, respectively [16].

\section{Types of Cements and Their Composition and Uses}

There are over ten different types of cements that are used in construction purposes, and they differ by their composition and are manufactured for different uses. These are rapidhardening cement (RHC), quick-setting cement (QSC), lowheat cement (LHC), sulphate-resisting cement (SRC), blast furnace slag cement (BFSC), high-alumina cement (HAC), white cement (WC), coloured cement (CC), pozzolanic cement $(\mathrm{PzC})$, air-entraining cement (AEC), and hydrophobic cement (HpC). RHC has increased the lime content compared to the Portland cement (PC) $[17,18]$. Purpose of having high lime content is to attain high strength in early days. It is used in concrete when formwork is to be removed early. Since hardening of cement is due to the formation of $\mathrm{CaCO}_{3}$ by absorbing atmospheric $\mathrm{CO}_{2}$ by $\mathrm{CaO}$, increased $\mathrm{CaO}$ results in increased $\mathrm{CaCO}_{3}$ formation even at the early stage to result in rapid hardening [19]. 
TABle 2: Composition of components as wt.\% used to make different types of cements.

\begin{tabular}{lccccc}
\hline Component & Portland cement & Siliceous fly ash & Calcareous cement & Slag cement & Fume silica \\
\hline $\mathrm{SiO}_{2}$ & 21.9 & 52.0 & 35.0 & 35.0 & $85-97$ \\
$\mathrm{Al}_{2} \mathrm{O}_{3}$ & 6.9 & 23.0 & 18.0 & 6.0 & 12.0 \\
$\mathrm{Fe}_{2} \mathrm{O}_{3}$ & 3.9 & 11.0 & 21.0 & 40.0 & 0 \\
$\mathrm{CaO}$ & 63.0 & 5.0 & 0 & 0 & 0 \\
$\mathrm{MgO}$ & 2.5 & 0 & 0 & 0 & 0 \\
$\mathrm{SO}_{3}$ & 1.7 & 0 & 0.42 Blaine & 0.40 Blaine & $15-30 \mathrm{BET}$ \\
$\mathrm{SSA}\left(\mathrm{m}^{2} \cdot \mathrm{g}^{-1}\right)$ & 0.37 Blaine & 0.42 Blaine & 2.65 & 2.94 \\
$\mathrm{SG}$ & 3.15 & 2.38 & 2.22 \\
\hline
\end{tabular}

SSA = specific surface area; $S G=$ specific gravity. Adapted from [13-15].

QSC is produced by adding a small percentage of aluminium sulphate as an accelerator and reducing the amount of gypsum used with fine grinding. This cement is used when the work is to be completed very quickly as in static and running waters. $\mathrm{LHC}$ has reduced the amount of $\mathrm{C}_{3} \mathrm{~A}$, which is used to produce massive concrete constructions like gravity dams. LHC has compressive strength to heat of the hydration ratio of at least 7 at the age of 13 weeks. The usual wt. ratio of $\mathrm{CaO}$ to $\mathrm{SiO}_{2}$ is between 0.8 and 1.5, but $\mathrm{Al}_{2} \mathrm{O}_{3}$ wt.\% is less than $10 \%$ [20]. This is prepared by grinding the $\mathrm{CaO}, \mathrm{SiO}_{2}$, and $\mathrm{Al}_{2} \mathrm{O}_{3}$ materials, melting the mixture, quenching the melt, and grinding the quenched matter to have mainly amorphous material of the above composition. Alumina is a hydratable material and reduced alumina gives reduced hydration to produce less heat of hydration. This is important in the construction of large structures to avoid possible thermal cracking during concrete setting [21].

Sulphate attack on concrete is a chemical breakdown mechanism, where sulphate reacts with $\mathrm{C} 3 \mathrm{~A}$ and/or $\mathrm{Ca}(\mathrm{OH})_{2}$ components of the hardened cement forming ettringite, which is hexacalcium aluminate trisulphate hydrate $\left[(\mathrm{CaO})_{6}\left(\mathrm{Al}_{2} \mathrm{O}_{3}\right)\left(\mathrm{SO}_{3}\right) 32 \mathrm{H}_{2} \mathrm{O}=\mathrm{C}_{6} \mathrm{ASH}_{32}\right]$. Sulphate ions can react with $\mathrm{C}_{3} \mathrm{~A}$ and/or $\mathrm{Ca}(\mathrm{OH})_{2}$ in hardened concrete in the presence of water forming gypsum. These newly formed ettringite and gypsum crystals occupy empty spaces of concrete, and as they grow, they tend to damage the paste by cracking. The most important parameters determining the sulphate attack are $\mathrm{C}_{3} \mathrm{~A}, \mathrm{C}_{3} \mathrm{~S} / \mathrm{C}_{2} \mathrm{~A}$ ratio, and $\mathrm{C}_{4} \mathrm{AF}$. It has been reported that the addition of pozzolonic admixtures such as fly ash reduces the $\mathrm{C}_{3} \mathrm{~A}$ content of cement [22] when sulphate is present in water and soil used; in places like canal linings, culverts, retaining walls, and siphons, it is important to use SRC. SRC is prepared by maintaining $\mathrm{C}_{3} \mathrm{~A}$ content below $6 \%$.

BFSC is prepared by grinding the clinkers with $\sim 60 \%$ slag. BFSC resembles properties of the Portland cement and is used for works in which economic considerations are predominant. HAC is obtained by melting a mixture of bauxite and lime and grinding the mixture with the clinker. Since it contains high alumina content, it is rapid-hardening cement with initial and final setting times of about $3.5 \mathrm{~h}$ and $5 \mathrm{~h}$, respectively [22]. HAC is used in works where concrete is subjected to high temperatures, frost, and acidic conditions. WC is prepared from raw materials free from iron oxides and oxides of other transition metals such as $\mathrm{Cr}$, $\mathrm{Mn}, \mathrm{Cu}, \mathrm{V}$, and Ti. The colouring effect takes the order
$\mathrm{Cr}_{2} \mathrm{O}_{3}>\mathrm{Mn}_{2} \mathrm{O}_{3}>\mathrm{Fe}_{2} \mathrm{O}_{3}>\mathrm{V}_{2} \mathrm{O}_{3}>\mathrm{CuO}>\mathrm{Ti}_{2} \mathrm{O}_{3}$. As such, the amounts of these transition metal ions, particularly $\mathrm{Cr}^{3+}$, $\mathrm{Mn}^{3+}$, and $\mathrm{Fe}^{3+}$, should be minimized to form white cement. Usually, $\mathrm{Cr}_{2} \mathrm{O}_{3}, \mathrm{Mn}_{2} \mathrm{O}_{3}$, and $\mathrm{Fe}_{2} \mathrm{O}_{3}$ are kept below $0.003 \%$, $0.03 \%$, and $0.35 \%$, respectively, in the clinker [23]. Cheap quarried raw materials usually contain $\mathrm{Cr}, \mathrm{Mn}$, and Fe. For example, lime stones and clays usually contain $0.3-1 \%$ and $5-15 \% \mathrm{Fe}_{2} \mathrm{O}_{3}$. Keeping $\mathrm{Fe}_{2} \mathrm{O}_{3}$ below $0.5 \%$ is desirable to make WC, and as such, kaolin and sand are used instead of other clays in making WC. The abrasiveness of sand particles with size $<45 \mu \mathrm{m}$ also ensures less wearing of chrome-steel grinding mill used to grind raw materials, which would otherwise contaminate the mixture with Fe and Cr. Usually, sand is ground separately using ceramic grinding media to avoid chromium contamination. WC is costly and hence used in aesthetic applications such as precast curtain wall and facing panels and terrazzo surface. Contrary to WC, CC is prepared by deliberately adding mineral pigments to cement. CCs are widely used in decorative works on floors. Iron oxides are used to get red, yellow, and black base colours, and several mixed colours such as brownsterracotta-tuscany-sepia-beach. Standard green and blue pigments are chrome oxide and cobalt aluminium oxide, respectively. $\mathrm{TiO}_{2}$ is the usual white pigment. $\mathrm{PzC}$ is prepared by grinding the pozzolanic clinker with the Portland cement [24]. It is used in marine structures, sewage works, and for laying concrete under water such as in bridges, piers, and dams.

AEC is produced by adding air-entraining agents that are surfactants such as alkali salts of wood resins, synthetic detergents of the alkyl-aryl sulphonate type, calcium lignosulphate derived from the sulphite process in paper making, and calcium salts of glues and other proteins obtained in the treatment of animal hides, animal and vegetable fats, oil and their acids, wetting agents, aluminium powder, and hydrogen peroxide, during the grinding of the clinker [25]. They are added in $0.025-0.1 \%$ in either solid or liquid form. At the time of mixing, AEC produces tough, tiny, discrete noncoalescing air bubbles of $10-500 \mu \mathrm{m}$ in diameter in the body of the concrete. These bubbles can compress to some extent, and hence, they can absorb stress created by freezing.

$\mathrm{HpC}$ is prepared by adding water-repellent chemicals [26]. They are prepared particularly for use in high-rainfall regions to prevent water absorption during storage. Particles of $\mathrm{HpC}$ are coated with nonpolar substances, usually by 
TABLE 3: Masses of emitted pollutants from the European cement kilns per year.

\begin{tabular}{lc}
\hline Pollutant & Mass emitted (tonnes per year) \\
\hline $\mathrm{CO}_{2}$ & 1.5456 million \\
$\mathrm{CO}$ & $460-11500$ \\
$\mathrm{SO}_{2}$ & $\mathrm{Up}$ to 11125 \\
$\mathrm{NO}_{x}$ as $\mathrm{NO}_{2}$ & $334-4670$ \\
Dust & $0.62-522$ \\
$\mathrm{TOC} / \mathrm{VOC}$ & $2.17-267$ \\
$\mathrm{HCl}$ & $0.046-46$ \\
$\mathrm{HF}$ & $0.21-23.0$ \\
PCCD/PCDF & $0.0000276-0.627$ g per year \\
\hline
\end{tabular}

Adapted from http://ena.lp.edu.ua:8080/bitstream/ntb/16692/1/55-Stajanca-296302.pdf.

adsorbing oleic acid, stearic acid, and so on, to cement particles $[27,28]$. When adsorbed, these surfactant molecules self-assemble by coordinating with surface cations through their carboxylic acid groups thereby allowing the nonpolar hydrocarbon chain to extend from the particles. When a water drop falls on them, they are stuck on hydrocarbon chains and stay as spherical particles as does by the lotus leaf. The cement particles are then not wetted, and water drops roll off when slightly slanted. These hydrophobic coatings prevent the attacks by chloride and sulphate ions, and hence, they resist to deterioration of concretes by these ions [29].

\section{Environmental Effects of Cement Manufacturing}

Measured data of the European cement kiln emissions show that cement industry contributes substantially to environmental pollution. Table 3 lists main environmental pollutants emitted by the European cement kilns in tonnes per year.

TOC/VOC, PCCD, and PCDF indicate total organic compounds including volatile organic compounds, polychlorinated dibenzo- $p$-dioxins, and polychlorinated dibenzofurans, respectively. It has been reported that toxic metals such as $\mathrm{Hg}, \mathrm{Cd}, \mathrm{Tl}, \mathrm{As}, \mathrm{Sb}, \mathrm{Pb}, \mathrm{Cr}, \mathrm{Co}, \mathrm{Cu}, \mathrm{Mn}, \mathrm{Ni}$, and $\mathrm{V}$ are also emitted in considerable amounts. For example, masses of $\mathrm{Hg}, \sum(\mathrm{Cd}, \mathrm{Tl})$, and $\sum(\mathrm{As}, \mathrm{Sb}, \mathrm{Pb}, \mathrm{Cr}, \mathrm{Co}$, $\mathrm{Cu}, \mathrm{Mn}, \mathrm{Ni}, \mathrm{V})$ emitted in kg per year are $0-1311,0-1564$, and $0-9200$, respectively [30]. In addition to material pollutants, noise emission is also associated with almost all the processes involved in cement manufacturing. These environmental impacts contribute to abiotic depletion, global warming, acidification, and marine ecotoxicity [31].

Cement is produced by utilizing an extensive amount of raw materials treated and reacted at extreme conditions such as high temperatures. The high-temperature processes are called pyroprocessing processes where raw materials are heated at high temperatures for solid-state reactions to take place, which utilize fuel sources such as coal, fuel oil, natural gas, tires, hazardous wastes, petroleum coke, and basically anything combustible [32]. Some cement manufacturing plants utilize the organic waste generated in other industries such as rubber processing industries. As such, cement industry contributes to a significant extent of anthropogenic carbon dioxide emissions, which is in the range of 5-7\% of total anthropogenic carbon dioxide emissions [33]. In the clinker burning process, in order to produce 1 tonne of clinkers, 1.52 tonnes of raw materials are used on average. The balance of 0.52 tonne of raw materials is converted mainly to carbon dioxide by the processes such as $\mathrm{CaCO}_{3} \rightarrow$ $\mathrm{CaO}+\mathrm{CO}_{2}$. This is a serious global environmental problem since increase in carbon dioxide in the atmosphere has direct consequences on global warming. In addition to $\mathrm{CO}_{2}$, other key polluting substances emitted to air by the cement industry include dust, other carbon oxides such as carbon monoxide $(\mathrm{CO})$, nitrogen oxides $\left(\mathrm{NO}_{x} \mathrm{~s}\right)$, sulphur oxides $\left(\mathrm{SO}_{x} \mathrm{~s}\right)$, polychlorinated dibenzo-p-dioxins, dibenzofurans, total organic carbon, metals, hydrogen chloride, and hydrogen fluoride, which are serious health-hazardous substances and some are hilariously odorous [34]. However, the type and amount of air pollution caused by the cement industry depend on various parameters, such as inputs (the raw materials and fuels used) and the type of process used in the industry.

As for water pollution, the contribution from cement industry may be insignificant through the storage and handling of fuels that may contribute to soil and groundwater contaminations [35]. In order to reduce the amount of raw materials, particularly in the manufacturing of specialized cement types as described above, supplementary cementitious materials such as coal fly ash, slag, and natural pozzolans such as rice husk ash and volcanic ashes are used. This will not only reduce the waste materials generated for landfilling but also the cost of cement production [36].

However, cement is an essential material for human survival nowadays. As such, there is no alternative, but the production of cement is mandatory. At the same time, controlling pollution created by cement industry is also very important. In the next section, we discuss ways and means of controlling pollution resulting from cement industries.

\section{Pollution Control in Cement Manufacturing}

The air pollution occurs in the excavation activities, dumps, tips, conveyer belts, crushing mills, and kilns of cement industry. Minimizing air pollution is a mandatory legislative requirement, which also contributes to minimizing wastage and survival of the industry [37]. Dust particles emitted at sites other than kilns can be captured using a hood or other partial enclosure and transported through a series of ducts to the collectors. The dust collected can be fed to the kiln provided that it is not too alkaline not exceeding $0.6 \%$ as per the $\mathrm{Na}_{2} \mathrm{O}(\mathrm{N})$ content. However, if the alkalinity is higher than this value, then the dust must be either discarded or pretreated before feeding to the kiln. Flexible pulse jet filters, electrostatic precipitators, wet scrubbers, and baghouse method can be used to collect dust from flue gas [38]. The US Environmental Protection Agency has reviewed the available and emerging technologies for reducing greenhouse gas emissions from Portland cement industry. The primary greenhouse gas emitted in the cement industry is carbon 
dioxide, but in lower quantities, $\mathrm{NO}_{x} \mathrm{~s}$ and $\mathrm{SO}_{x} \mathrm{~s}$ are also emitted as detailed in Table 3 [39].

4.1. Carbon Capture and Storage. This involves separation and capture of carbon dioxide from the flue gas, pressurization, and transportation via pipelines, injection, and longterm storage. In regard to this, several processes have been developed as detailed below.

4.1.1. Calera Process. This involves capture of $\mathrm{CO}_{2}$ from flue gas and conversion to carbonates. This utilizes a scrubber containing high-pH water with calcium, magnesium, sodium, hydroxide, and chloride as the scrubbing liquid. $\mathrm{CO}_{2}$ captured by this water is converted to $\mathrm{CaCO}_{3}$ and $\mathrm{MgCO}_{3}$, which are precipitated out of the solution. The precipitates can be filtered, washed, and dried for reuse as feed material for the kiln to make blended cement. Water used may be seawater or reject brine. Capture efficiency of over $90 \%$ has been reported in a 10 -MW coal-fired pilot plant. It is interesting to note that when captured carbon is reused, the overall carbon footprint becomes negative since the carbon emissions avoided from the cement manufacturing process could be greater than those of carbon emissions from the power plant $[39,40]$.

4.1.2. Oxy-Combustion Process. In the oxy-combustion process, fuel is burnt with pure or nearly pure oxygen instead of air. Since there is no nitrogen gas, the fuel consumption is reduced due to the fact that there is no need to heat and burn nitrogen gas. Since air contains nearly $79 \%$ nitrogen gas and any combusted nitrogen comes as $\mathrm{NO}_{x}$ in flue gas, the volume of flue gas and $\mathrm{NO}_{x}$ in it is significantly reduced when pure oxygen is used for combustion [39, 41]. This process should utilize an air separation process to separate out nitrogen gas, which can be used for other processes such as for inflating vehicle tires. Nitrogenremoved air basically contains majority of oxygen, and it can be used for the oxy-combustion process. When oxycombustion is used, the resulting kiln exhaust contains over $80 \% \mathrm{CO}_{2}$ gas, which can be recovered by the Calera process. There are several technical issues as laid down in [42] that have to be tackled before implementing this process in cement industry.

4.1.3. Monoethanolamine (MEA) Process. When flue gas is passed through a column containing monoethanolamine, $\mathrm{CO}_{2}$ gas is selectively absorbed. High-pressure, low-temperature conditions favour the absorption. When $\mathrm{CO}_{2}$-rich MEA solution is subjected to low-pressure, high-temperature conditions, it releases absorbed $\mathrm{CO}_{2}$ which can be converted to some other product like $\mathrm{CaCO}_{3}$ or $\mathrm{MgCO}_{3}$ and the solvent recovered can be reused. One of the problems with this method is that acidic gases such as $\mathrm{SO}_{x}$ and $\mathrm{NO}_{x}$ present in the flue gas can react with MEA. Therefore, levels of these gases must be kept below $0.001 \%$ prior to absorption by MEA. Instead of regular amines, hindered amines can also be used. Hindered

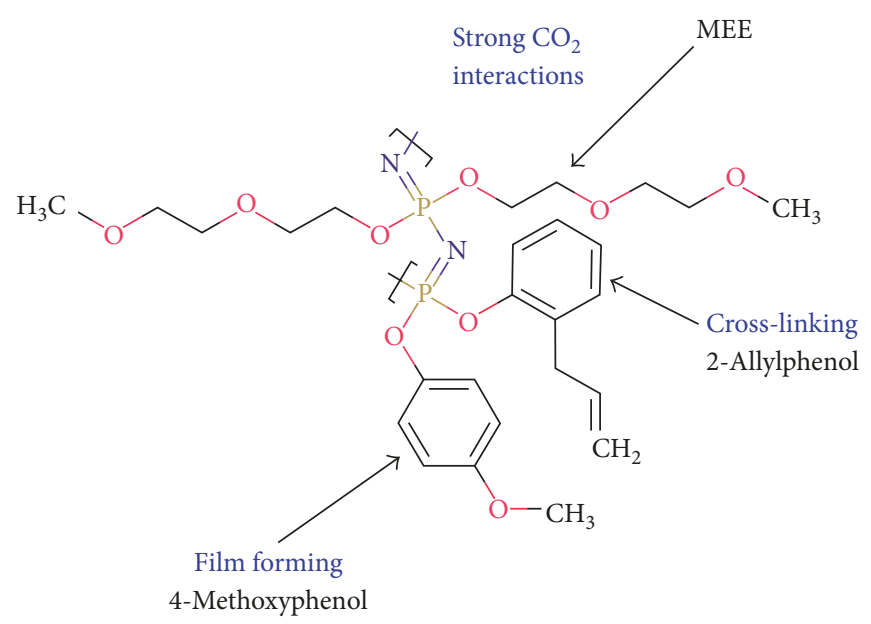

FIgURE 1: General structure of stabilized poly(methoxyethoxy) ethanol phosphazene hollow fibre membrane.

amines have special functional to prevent degradation of the amine [43].

4.1.4. Flue Gas Desulphurized Mixture. Flue gas contains $\mathrm{SO}_{x}$, which could be separated using limestone-based compounds. They are then converted to slurries to use as $\mathrm{CO}_{2}$ absorbents. This way, both $\mathrm{SO}_{x}$ and $\mathrm{CO}_{2}$ can be removed from flue gas [43].

4.1.5. Cryogenic Distillation. Cryogenics is the science that addresses the production and effects of very low temperatures. In the cryogenic separation, all other gases except $\mathrm{CO}_{2}$ and $\mathrm{N}_{2}$ have to be removed prior to subjecting to lowtemperature conditions. The triple point for $\mathrm{CO}_{2}$ is $256.68^{\circ} \mathrm{C}$ and $7.4 \mathrm{~atm}$, and when these conditions are maintained, $\mathrm{CO}_{2}$ will condense while $\mathrm{N}_{2}$ will remain as a gas. $\mathrm{N}_{2}$ gas is then escaped through an outlet at the top of the chamber, and the dense liquid is taken from the bottom of the chamber. Refrigeration under pressure is an alternative method to cryogenic distillation but utilizes even harsh conditions such as higher pressures and lower temperatures. Cryogenic methods have distinct advantages over other separation methods. Since $\mathrm{CO}_{2}$ is separated as a liquid, it can be transported via pipelines for sequestration. Also, the recovery and purity of $\mathrm{CO}_{2}$ is very high $\left(\mathrm{CO}_{2}\right.$ purity after distillation can exceed 99.95\%) [43].

4.1.6. Membrane Separation. Suitable membranes can be used to separate or adsorb $\mathrm{CO}_{2}$ in the kiln exhaust gas. Poly (methoxyethoxy)ethanol phosphazene (MEEP) hollow fibre membranes are excellent $\mathrm{CO}_{2}$ separation and storing membranes, where (methoxyethoxy)ethanol groups attached $\mathrm{P}$ have strong interactions with $\mathrm{CO}_{2}$ [44-46]. One such example is given in Figure 1.

Polymer blends with required properties such as strong interaction with $\mathrm{CO}_{2}$ can be used as $\mathrm{CO}_{2}$-selective membranes. For example, cross-linked thin-film composite of poly(vinylalcohol) (PVA)/polyvinylpyrrolidone (PVP) blend 


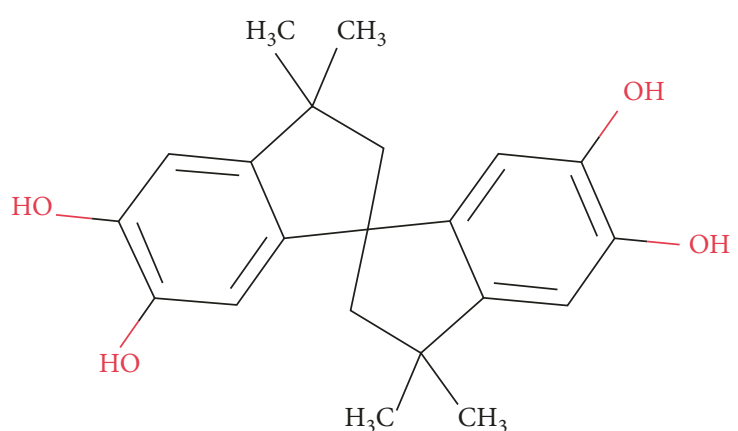

(a)

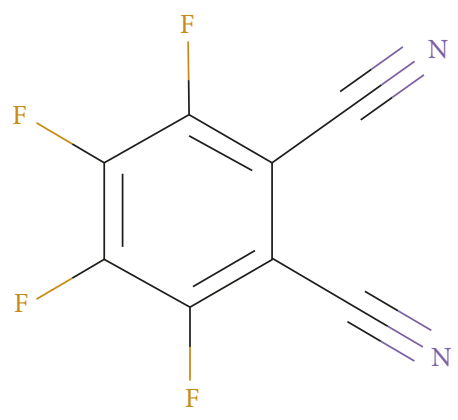

(b)

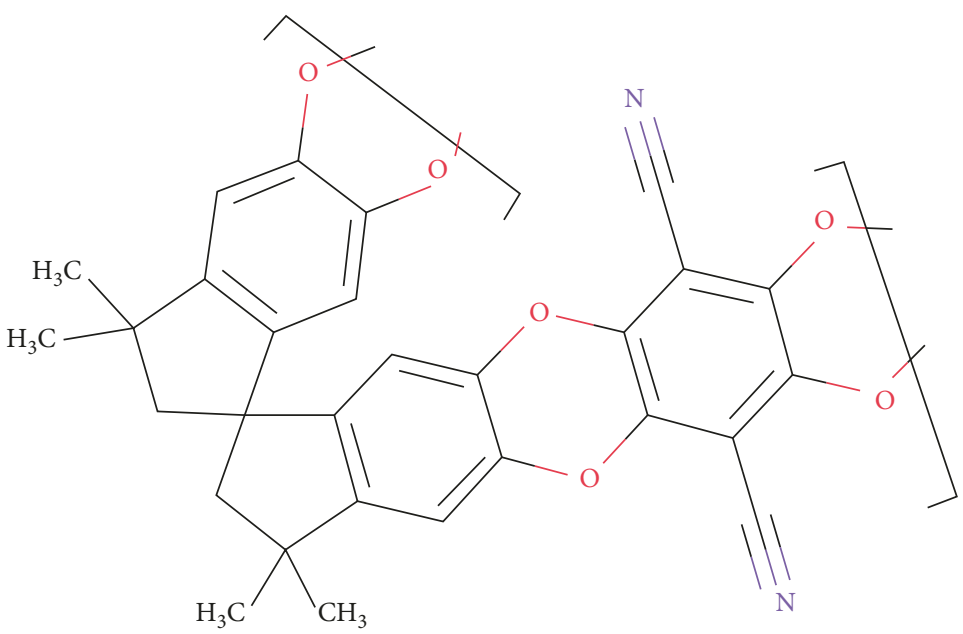

(c)

FiguRe 2: Chemical structures of (a) 5,5,6,6-tetrahydroxy-3,3,3,3-tetramethylspiro-bisindane, (b) tetrafluorophthalonitrile, and (c) polycondensate polymer PIM-1 [49].

membranes doped with suitable amine carriers are excellent $\mathrm{CO}_{2}$-selective membranes as reported by Mondal and Mandal. The $\mathrm{CO}_{2}$ permeability of this membrane is 1396 Barrer at $2.8 \mathrm{~atm}$ and $100^{\circ} \mathrm{C}$ [47]. Combination of grafting and crosslinking is an advanced technique capable of suppressing plasticization. In this respect, Achoundong et al. developed cellulose acetate (CA) membranes and grafted vinyltrimethoxysilane (VTMS) to -OH groups, which due to subsequent condensation of hydrolyzed methoxy groups on the silane form cross-linked polymer networks. The modified membranes have an order of magnitude higher $\mathrm{CO}_{2}$ permeability than neat cellulose acetate membranes [48].

Polymers of intrinsic microporosity (PIMs), thermally rearranged polymers (TRPs), polyimides, and polyurethanes are advanced polymers with high selectivity for $\mathrm{CO}_{2}$ and hence are suitable membranes for $\mathrm{CO}_{2}$ separation. PIMs are ladder polymers with high free volume and high selectivity for $\mathrm{CO}_{2}$. These ladder polymer backbones can be prepared by polycondensation reaction of tetrahydroxy monomers containing spiro- or contorted centres with tetrafluoromonomers. One such example is the PIM-1 prepared by the polycondensation reaction of commercial monomers such as 5,5,6,6-tetrahydroxy-3,3,3,3-tetramethyl-1,1' -spiro-bisindane with tetrafluorophthalonitrileo. Chemical structures of the monomers are given in Figure 2.
These polymers have high $\mathrm{CO}_{2}$ solubility and spirocentres, such as thianthrene [50], 9,10-dimethyl-9,10dihydro-9,10-ethanoanthracene [51], ethanoanthracene [52], and pyrazine [53], and could be incorporated in PIM membranes for adjusting the gas permeation properties.

Thermally rearranging polymers (TRPs) are prepared by a thermal postmembrane conversion process of functionalized polyimides. They have uniform cavities with tailored free-volume elements with well-connected morphology in the amorphous state [54]. For example, thermal rearrangement of poly(hydroxyimide)s is shown in Figure 3.

TRPs have good $\mathrm{CO}_{2} / \mathrm{CH}_{4}$ separation performance, good resistivity to $\mathrm{CO}_{2}$-induced plasticization, and high chemical resistivity [55].

4.2. Adsorption of $\mathrm{CO}_{2}$ into Advanced Sorbents. Separation of $\mathrm{CO}_{2}$ from a gas mixture by selective adsorption involves both thermodynamics (adsorption) and kinetics (diffusion selectivity), and designing adsorbents for $\mathrm{CO}_{2}$ in the presence of gases such as $\mathrm{CH}_{4}$ and $\mathrm{N}_{2}$ is challenging since all three gases have similar kinetic diameters of $3.30 \AA$, $3.76 \AA$, and $23.64 \AA$, respectively [55]. In this sense, sorbents such as zeolites and metal-organic frameworks (MOFs) stand out as adsorbents of $\mathrm{CO}_{2}$. 


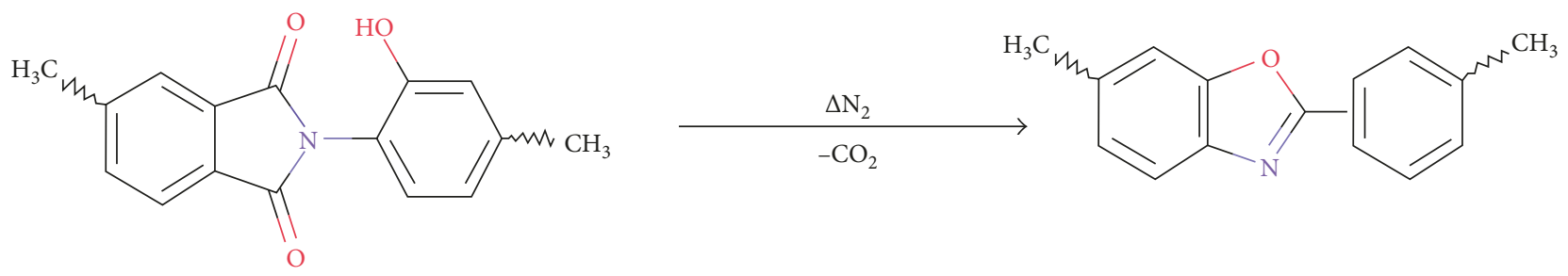

FIgURE 3: Thermal rearrangement of poly(hydroxyimide)s.

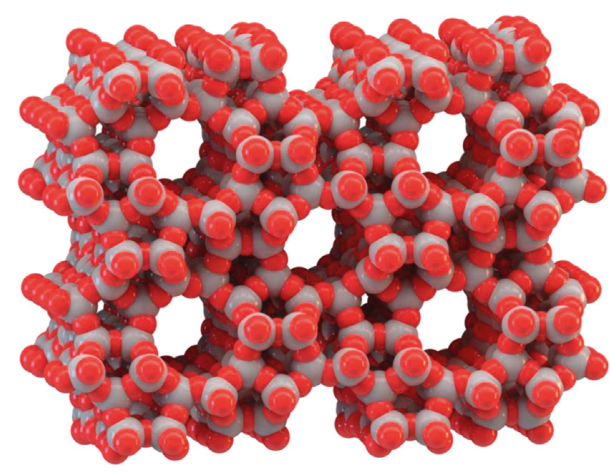

FIgURE 4: The microporous molecular structure of zeolite, ZSM-5. (Thomas Splettstoesser (www.scistyle.com), own work, CC BY-SA 4.0, File:Zeolite-ZSM-5-vdW.png (created: 23 June 2015); https: //en.wikipedia.org/wiki/Zeolite (accessed: June 11, 2017)).

4.3. Zeolites. Zeolites are microporous aluminosilicate minerals such as analcime, chabazite, clinoptilolite, heulandite, natrolite, phillipsite, and stilbite. Figure 4 shows the microporous molecular structure of zeolite, ZSM-5. Synthetic zeolites are prepared by the slow crystallization of a silica-alumina gel in the presence of alkalis and organic templates.

Zeolites are added to the Portland cement as a pozzolan and water reservoir to reduce chloride permeability and to improve workability. Siriwardane et al. have studied competitive gas adsorption properties of zeolites 13X, 4A, 5A, UOP-WE-G 592, and UOP APG-II with gas mixtures containing $\mathrm{CO}_{2}$ and found that all of them have good $\mathrm{CO}_{2}$ adsorption capacities down to ppm levels from a gas mixture containing $15 \% \mathrm{CO}_{2}, 3 \% \mathrm{O}_{2}$, and $83 \% \mathrm{~N}_{2}$ [56]. Zeolites are microporous and aluminosilicate minerals commonly used as commercial adsorbents. Zeolite has been used for trapping $\mathrm{CO}_{2}$ from ice or air [57]. A zeolite trap was also used as an alternative to a cryogenic trap for collecting $\mathrm{CO}_{2}$ from oxidation of organic carbon. The selective gas absorption and desorption characteristics of zeolite as a function of temperature will be useful for simplifying the system for trapping $\mathrm{CO}_{2}$ and transferring the gas to a graphitization reactor [58].

4.4. Metal Organic Frameworks (MOFs). Metal organic frameworks (MOFs) are yet another good sorbents for $\mathrm{CO}_{2}$. Their structures are composed of metal-containing nodes linked by organic ligand bridges, which are assembled through strong coordination bonds (Figure 5) [59].

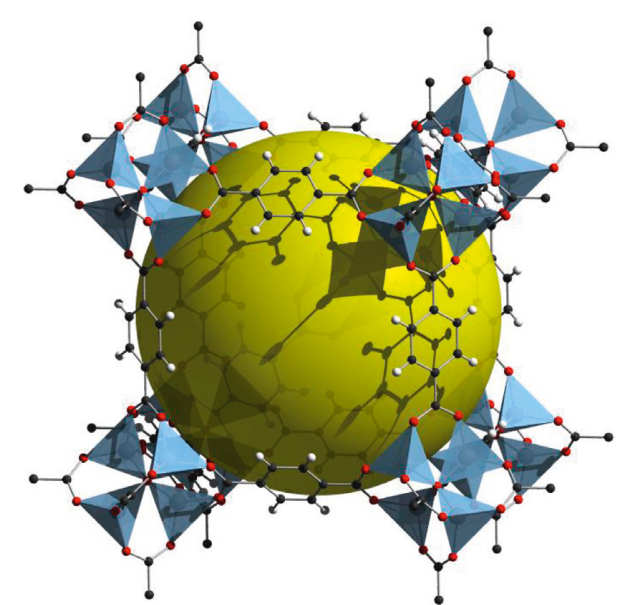

Figure 5: An example for MOF: MOF-5. Large pore is shown with the yellow ball (Tony Boehle, own work: https://en.wikipedia. org/wiki/Metal-organic_framework\#/media/File:IRMOF-1_wiki.png).

Compared to other $\mathrm{CO}_{2}$ sorbents such as zeolites and activated carbon, MOFs have higher pore volume and surface area and hence have higher $\mathrm{CO}_{2}$ sorption capacity $[60,61]$. Adsorption is the process of entrapping atoms or molecules which are incident on a surface; hence, the adsorption capacity of a material concerned increases with respect to its surface area. In $3 \mathrm{D}$ nature, the maximum surface area would be obtained by a structure that is highly porous such that molecules and atoms can access internal surfaces of the materials. It clearly suggests that the highly porous metal organic frameworks (MOFs) should have to have an excellent ability of entrapping $\mathrm{CO}_{2}$. Generally, the most successful MOFs demonstrate extremely high BET surface areas of $4,000-7,000 \mathrm{~m}^{2} \cdot \mathrm{g}^{-1}$ with many also possessing coordinatively unsaturated metal sites [62]. In order to gain high efficiency of $\mathrm{CO}_{2}$ entrapment inside the $\mathrm{MOF}$ and for the development of higher performance MOFs, the interior part of MOFs should be designed to have coordinative porosity, hydrophobicity, defects and embedded nanoscale metal catalysts, unsaturated metallic suitable sites, specific heteroatoms, and other building unit interactions [63]. Some examples of MOFs capable of $\mathrm{CO}_{2}$ sorption are $\mathrm{Ni}_{2}{ }_{2} \mathrm{Ni}^{\mathrm{III}}\left(\mu_{3}-\mathrm{OH}\right)(\mathrm{pba})_{3}(2,6-\mathrm{ndc})_{1.5}(\mathrm{MCF}-19$; $\mathrm{pba}=4$ - (pyridin-4-yl)benzoate, $2,6-\mathrm{ndc}=2,6$-naphthalenedicarboxylate), $\mathrm{Zn}_{4} \mathrm{O}(\mathrm{bdc})_{3}$ (MOF-5 or IRMOF-1, $\mathrm{bdc}=1$,4-benzenedicarboxylate), $\mathrm{Zn}_{4} \mathrm{O}(\mathrm{btb})_{2}$ (MOF-177, $\mathrm{btb}=$ benzene-1,3,5-tribenzoate), and $\mathrm{Zn}_{4} \mathrm{O}(\mathrm{bte})_{14 / 9}(\mathrm{bpdc})_{6 / 9}$ (MOF-210, bte $=4,4,4$-(benzene-1,3,5-triyltris(ethyne-2,1diyl))tribenzoate, bpdc $=$ biphenyl-4,4-dicarboxylate) [64-66] . 


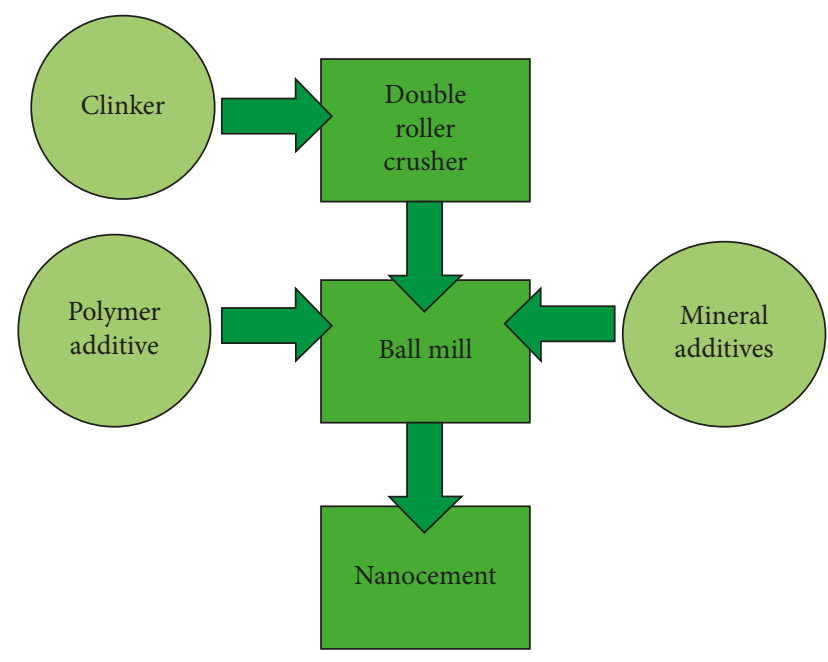

FIGURE 6: Schematic representation of the nanocement production process.

\section{Nanocement}

Nanocement is the cement produced by mechanical activation of nuclear cement particles in the size range $2-3 \mu \mathrm{m}$ by coating with 10 to $100 \mathrm{~nm}$-thick membranes of modifier materials. More than $65 \%$ of mineral supplements such as sand, ash, slag, and tuff and polymer additives are used as modifier materials [67]. The development of modern cement and concrete industry seeks for the improvement of the durability of the materials by the addition of required amount of nanoparticles, or nano-based structure of cement-based materials can be improved. Frequently used nanoparticles are nanosilica, nanoclay, and carbon nanotubes $[68,69]$. Improvement of durability of the materials is approached through alteration of the physicochemical properties of the binder. In addition, usages of nanoclay and carbon nanotubes can decrease the transport property, optimize microstructure, and decrease the volume instability of cement-based materials. The process of nanocement production is shown schematically in Figure 6. It has been reported that nanocement can be used to produce $500-800$ brands of high-strength concretes and 1300-1500 brands of heavy-duty concretes [70]. "US Patent on Method for producing nano-cement, and nano-cement" [71] deals with the procedure developed to produce nanocement, which involves mechanochemical activation of dispersed grains of the Portland cement in the presence of a polymeric modifier. They used at least $60 \%$ by wt. of sodium naphthalenesulfonate and mineral siliceous additive containing at least 30 wt. $\% \mathrm{SiO}_{2}$ and gypsum to form nanoshells around cement grins. Capsules of 20-100 nm thickness are formed around Portland cement grains, which are made of sodium naphthalenesulfonate and structured by calcium cations. Subsequent to mechanochemical activation, the resultant material is ground to a specific surface area of $300-900 \mathrm{~m}^{2} \cdot \mathrm{kg}^{-1}$. Nanocement improves the technical quality of the Portland cement, reduces cost of production due to the use of $70 \mathrm{wt} . \%$ mineral additives, 1.2-2 times reduction of the fuel cost, and
2-3 times reduction of emission of $\mathrm{NO}_{x}, \mathrm{SO}_{2}$, and $\mathrm{CO}_{2}$ per tonne of cement. Nanocement has very high performance; for instance, the deflection strength of nanocement-based concrete and ordinary Portland cement-based concrete at 2-day hardening are around 6.3-7.1 $\mathrm{MPa}$ and 2.9 $\mathrm{MPa}$ with corresponding compressive strengths of $49.3-54.7 \mathrm{MPa}$ and 21.3 $\mathrm{MPa}$, respectively. At 28-day hardening, deflection strength improves to $8.2-8.7 \mathrm{MPa}$ and $6.4 \mathrm{Mpa}$, respectively, while compressive strength improves to $77.5-82.7 \mathrm{MPa}$ and 54.4 $\mathrm{MPa}$, respectively [72].

Use of nano-graphite as an additive in cement is also currently under investigation. Use of graphite nanoparticles in cement is expected to not only improve mechanical properties but also improve faster curing time, inhibition of premature failure in concretes, and ability to withstand large external forces produced in earthquakes and explosions [73]. The use of less concrete is also possible which means eventual contribution to the production of less Portland cement and hence reduction of consequent environmental problems associated with Portland cement manufacturing [74]. Other nanofillers used to improve properties of Portland cement include nanotitania $\left(\mathrm{TiO}_{2}\right)$, carbon nanotubes, nanosilica $\left(\mathrm{SiO}_{2}\right)$ and nanoalumina $\left(\mathrm{Al}_{2} \mathrm{O}_{3}\right)$, nanohematite/iron oxide (iii) $\left(\mathrm{Fe}_{2} \mathrm{O}_{3}\right)$, nano-magnetite/iron oxide (ii) $\left(\mathrm{Fe}_{3} \mathrm{O}_{4}\right)$, nano- $\mathrm{ZnO}_{2}$, nano- $\mathrm{ZrO}_{2}$, nano- $\mathrm{Cu}_{2} \mathrm{O}_{3}$, nano- $\mathrm{CuO}$, nano$\mathrm{CaCO}_{3}$, as nanotubes or fibres (carbon nanotubes and carbon nanofibers, and nano-clay).

According to the Feldman-Sereda model, the cement paste consists principally of gel pores, capillary pores, and an interlayer of water. In the concrete, there is an interfacial transition zone between the cement paste and the aggregates, which establishes a weak link in the concrete, basically the site at which the first cracks occur. Hence, it is significant to generate crack-free concrete with the possible incorporation of nanosilica to pursue [75]. Chen et al. demonstrated that $\mathrm{TiO}_{2}$ is an inert and stable compound during the cement hydration process, in which the total porosity of the cement pastes decreased, so that the pore size distribution is also changed. Normally, the acceleration of the hydration rate and the change in the microstructure also affected the physical and mechanical properties of the cement-based materials. The nano- $\mathrm{TiO}_{2}$ role is to work as a catalyst in the cement hydration reactions. Water absorption and capillary absorption show a significant decrease when $\mathrm{TiO}_{2}$ nanoparticles are included in the concrete, as the nanoparticles represent as nanofillers and thereby improve the concrete's resistance to water permeability. Moreover, $\mathrm{TiO}_{2}$ nanoparticles can progress the filler effect, and also the great pozzolanic action of fine particles substantially rises the quantity of strengthening gel formed [76]. Nanomontmorillonite (NM) is the most common member of the smectite clay family, which is sometimes referred to as nanoclay. This kind of clay belongs to a general mineral group of clays, which have particles with a sheet-like structure in which the dimensions in two directions far exceed the thickness.

We have investigated the production of these nanoparticles from both top-down and bottom-up approaches. Top-down approach is more industrially viable since large quantities of bulk materials found naturally can be used to 
produce corresponding nanomaterials through particle size reduction. The top-down approach relies on reducing the size of bulk materials to the size of the nanorange of 1$100 \mathrm{~nm}$. This can be done by crushing bulk materials to make powders, sieving to different fractions, further crushing of large size fractions, and finally milling to obtain sizes in the nanorange. Sri Lanka is gifted with very high-purity quartz, which contains almost $100 \% \mathrm{SiO}_{2}$. This quartz can be used to obtain nanosized $\mathrm{SiO}_{2}$ particles. Our ongoing research in collaboration with the Sri Lanka Industrial Technology Institute (ITI) is very successful, and we are able to produce $50 \mathrm{~nm}$ size $\mathrm{SiO}_{2}$ nanoparticles in large quantities by this topdown approach. We have also attempted converting ilmenite obtained from Sri Lanka Mineral Sand Corporation to produce nanotitania with great success. Birgisson et al. [77] summarized the key breakthroughs in concrete technology most probable to result from the usage of nanotechnology. Basically, it has shown the development of highperformance cement and concrete materials as measured by their mechanical and durability properties, development of sustainable concrete materials and structures through engineering for different adverse environments, reducing energy consumption during cement production and enhancing safety, improvement of intelligent concrete materials through the integration of nanotechnology-based self-sensing and self-powered materials and cyber infrastructure technologies, advancement of novel concrete materials through nanotechnology-based innovative processing of cement and cement paste, and also development of fundamental multiscale model(s) for concrete through advanced characterization and modeling of concrete at the nano-, micro-, meso-, and macroscale [78]. The frost resistance of concrete comprising nano- $\mathrm{Al}_{2} \mathrm{O}_{3}$ is better than that comprising the same amount of nano- $\mathrm{SiO}_{2}$. The compressive strength of normal concrete containing nano$\mathrm{SiO}_{2}$ is higher than that of the same amount of nano- $\mathrm{Al}_{2} \mathrm{O}_{3}$. The frost resistance of the concrete mixtures can be improved significantly by adding either nano- $\mathrm{Al}_{2} \mathrm{O}_{3}$ or nano$\mathrm{SiO}_{2}$. These nanomaterials not only promote the pozzolanic reaction, but they also act as fillers, thereby improving the pore structure of the concrete and densifying the microstructure of the cement paste. The frost resistance of the concrete containing nano- $\mathrm{Al}_{2} \mathrm{O}_{3}$ is better than that containing the same amount of nano- $\mathrm{SiO}_{2}$.

Nanoparticles have a large surface area to volume ratio than their bulk counterparts, and due to their small size, they can fill in small cavities of the cement matrix, densifying the structure to result in improved strength and faster chemical reactions such as hydration reactions associated with cement setting. Further, the material requirement can be reduced drastically thus saving fast depleting natural resources and energy requirements for cement manufacturing and reducing associated adverse environmental consequences.

\section{Conclusion}

Basically, different types of cements and their chemical composition and applications in the current engineering and chemical world have been discussed in detail. Different types of enhancing materials and fillers developed using nanotechnology for the productive and effective cement manufacturing have been mentioned with the chemical background. The mechanical defects when concrete is concerned and possible solutions that can be given through chemistry and nanotechnology have been deliberated in detail. In addition, $\mathrm{CO}_{2}$-entrapping chemical compounds such as zeolites and metal organic framework and their contribution in making durability of the cement manufacturing have been illustrated with their chemistry. Environment effects of cement manufacturing and how to control the pollution of the environment when manufacturing processes that are being executed have been discussed using several standard processes, including the Calera process, oxy-combustion process, and monoethanolamide (MEA) process. Currently, the applications of nanoscience and nanotechnology have been gaining popularity in different fields of science and technology. The potential of nanotechnology to progress the performance of concrete and to lead to the development of novel, sustainable, advanced cement-based composites, and smart materials with unique mechanical, thermal, and electrical properties is promising, and many novel opportunities are expected to arise in the future. So finally, the newest trend of making nanocement and its development towards current developing and updating world is described in advance.

\section{Conflicts of Interest}

The authors declare that there are no conflicts of interest.

\section{References}

[1] S. P. Dunuweera and R. M. G. Rajapakse, "Cement types, composition, uses, environmental impact and possible solutions," in Proceedings of the 28th International Symposium on Transport Phenomena, Peradeniya, Sri Lanka, September 2017.

[2] T. C. Powers and T. L. Brownyard, "Studies of the physical properties of hardened Portland cement paste," ACI Journal Proceedings, vol. 43, no. 9, pp. 101-132, 1946.

[3] F. Lea, The Chemistry of Cement and Concrete, February 2018, https:/ci.nii.ac.jp/naid/10003996296/.

[4] M. Schneider, M. Romer, M. Tschudin, and H. Bolio, "Sustainable cement production-present and future," Cement and Concrete Research, vol. 41, no. 7, pp. 642-650, 2011.

[5] A. Elimbi, H. Tchakoute, and D. Njopwouo, "Effects of calcination temperature of kaolinite clays on the properties of geopolymer cements," Construction and Building Materials, vol. 25, no. 6, pp. 2805-2812, 2011.

[6] M. Ali, R. Saidur, and M. Hossain, "A review on emission analysis in cement industries," Renewable and Sustainable Energy Reviews, vol. 15, no. 5, pp. 2252-2261, 2011.

[7] M. Thiery, G. Villain, P. Dangla, and G. Platret, "Investigation of the carbonation front shape on cementitious materials: effects of the chemical kinetics," Cement and Concrete Research, vol. 37, no. 7, pp. 1047-1058, 2018.

[8] Portland Cement Clinker: The Bogue Calculation, July 2017, http://www.understanding-cement.com/bogue.html\#.

[9] Composition of Cement, July 2017, http://www.engr.psu.edu/ ce/courses/ce584/concrete/library/construction/curing/ Composition $\% 20$ of\%20cement.htm. 
[10] S. Mindess and J. F. Young, Concrete, Prentice-Hall, Inc., Englewood Cliffs, NJ, USA, 1981.

[11] S. Kosmatka and W. Panarese, Design and Control of Concrete Mixtures, Portland Cement Association, Skokie, IL, USA, 1988.

[12] M. Mamlouk and J. Zaniewski, Materials for Civil and Construction Engineers, Addison Wesley Longman, Inc, Menlo Park, CA, USA, 1999.

[13] T. C. Holland, Silica Fume User's Manual, Technical Report FHWA-IF-05-016, Silica Fume Association and United States Department of Transportation Federal Highway Administration, Washington, DC, USA, 2005.

[14] S. Kosmatka, B. Kerkhoff, and W. Panerese, Design and Control of Concrete Mixtures, Portland Cement Association, Skokie, IL, USA, 14th edition, 2002.

[15] W. Gamble, "Cement, Mortar and Concrete," in Mark's Handbook for Mechanical Engineers, T. Baumeister and A. Avallone, Eds., p. 177, McGraw Hill, New York, NY, USA, 8th edition, 1916.

[16] Patents.google.com, "Portland cement manufacture," Patent No. US4081285A, 2018, https://patents.google.com/patent/ US4081285A/en.

[17] R. Medeiros-Junior and M. G. Lima, "Electrical resistivity of unsaturated concrete using different types of cement," Construction and Building Materials, vol. 107, pp. 11-16, 2016.

[18] M. Korsch and W. Walther, "Peri-implantitis associated with type of cement: a retrospective analysis of different types of cement and their clinical correlation to the peri-implant tissue," Clinical Implant Dentistry and Related Research, vol. 17, no. S2, pp. e434-e443, 2015.

[19] T. Matschei, B. Lothenbach, and F. Glasser, "The role of calcium carbonate in cement hydration," Cement and Concrete Research, vol. 37, no. 4, pp. 551-558, 2007.

[20] K. Nakatsu, T. Goto, T. Higaki, H. Endo, S. Hirose, and Y. Yamazaki, "Compositions for low heat cements," US Patent No. US5547505, 1996.

[21] R. Novotný, E Bartonípková, J Švec, and M Monpeková, "Influence of active alumina on the hydration process of Portland cement," Procedia Engineering, vol. 151, pp. 80-86, 2016.

[22] Sulphate Attack on Concrete-Process and Control of Sulphate Attack, July 2017, https://theconstructor.org/ concrete/sulphate-attack-on-concrete-prevention/2162/.

[23] A. Duran, J Fernandez Navarro, P. Mazon, and A. Joglar, "Coloured coatings containing mixed transition metal oxides," Journal of Non-Crystalline Solids, vol. 100, no. 1-3, pp. 494-500, 1988.

[24] I. Fernández Olmo, E. Chacon, and A. Irabien, "Influence of lead, zinc, iron (III) and chromium (III) oxides on the setting time and strength development of Portland cement," Cement and Concrete Research, vol. 31, no. 8, pp. 1213-1219, 2001.

[25] M. Murat and F. Sorrentino, "Effect of large additions of Cd, $\mathrm{Pb}, \mathrm{Cr}, \mathrm{Zn}$, to cement raw meal on the composition and the properties of the clinker and the cement," Cement and Concrete Research, vol. 26, no. 3, pp. 377-385, 1996.

[26] F. Tittarelli, "Oxygen diffusion through hydrophobic cementbased materials," Cement and Concrete Research, vol. 39, no. 10, pp. 924-928, 2009.

[27] I. J. de Vries and R. B. Polder, "Hydrophobic treatment of concrete," Construction and Building Materials, vol. 11, no. 4, pp. 259-265, 1997.

[28] A. M. AIshamsi, K. I. Alhosani, and K. M. Yousri, "Hydrophobic materials, superplasticizer and microsilica effects on setting of cement pastes at various temperatures," Magazine of Concrete Research, vol. 49, no. 179, pp. 111-115, 2015.
[29] O. S. Misnikov, "A study of the properties of portland cement modified using peat-based hydrophobic admixtures," Polymer Science Series D, vol. 7, no. 3, pp. 252-259, 2014.

[30] M. Stajanča and A. Eštoková, Environmental Impacts of Cement Production, July 2017, http://ena.lp.edu.ua:8080/bitstream/ntb/ 16692/1/55-Stajanca-296-302.pdf.

[31] C. Chen, G. Habert, Y. Bouzidi, and A. Jullien, "Environmental impact of cement production: Detail of the different processes and cement plant variability evaluation," Journal of Cleaner Production, vol. 18, no. 5, pp. 478-485, 2010.

[32] C. Branquinho, G. G. Oliveira, S. Augusto, P. Pinho, C. Máguas, and O. Correia, "Biomonitoring spatial and temporal impact of atmospheric dust from a cement industry," Environmental Pollution, vol. 151, no. 2, pp. 292-299, 2008.

[33] Y. Lei, Q. Zhang, C. Nielsen, and K. He, "An inventory of primary air pollutants and $\mathrm{CO}_{2}$ emissions from cement production in China, 1990-2020," Atmospheric Environment, vol. 45, no. 1, pp. 147-154, 2011.

[34] M. Schuhmacher, J. L. Domingo, and J. Garreta, "Pollutants emitted by a cement plant: health risks for the population living in the neighborhood," Environmental Research, vol. 95, no. 2, pp. 198-206, 2004.

[35] O. A. Al-Khashman and R. A. Shawabkeh, "Metals distribution in soils around the cement factory in southern Jordan," Environmental Pollution, vol. 140, no. 3, pp. 387-394, 2006.

[36] A. M. Farmer, "The effects of dust on vegetation-a review," Environmental Pollution, vol. 79, no. 1, pp. 63-75, 1993.

[37] K. T. Hindy, H. I. A. Shafy, and S. A. Faraga, "The role of the cement industry in the contamination of air, water, soil and plant with vanadium in Cairo," Environmental Pollution, vol. 66, no. 3, pp. 195-205, 1990.

[38] D. Zimwara, L. Mugwagwa, and T. R. Chikowore, "Air pollution control techniques for the cement manufacturing industry: a case study for Zimbabwe," in CIE42 Proceedings, Cape Town, South Africa, July 2012.

[39] Available and Emerging Technologies for Reducing Greenhouse Gas Emissions from the Portland Cement Industry (2010) Sector Policies and Programs Division Office of Air Quality Planning and Standards U.S. Environmental Protection Agency Research Triangle Park, North Carolina 27711, June 2017, https://www. epa.gov/sites/production/files/2015-12/documents/cement.pdf.

[40] Calera Inc., Notes on Sustainability and Potential Market, 2009.

[41] D. J. Barker, S. A. Turner, P. A. Napier-Moore, M. Clark, and J. E. Davison, " $\mathrm{CO}_{2}$ Capture in the Cement Industry," Energy Procedia, vol. 1, no. 1, pp. 87-94, 2009.

[42] A. D. Ebner and J. A. Ritter, "Carbon dioxide separations: state-of-the-art adsorption and membrane separation processes for carbon dioxide production from carbon dioxide emitting industries," Separation Science and Technology, vol. 44, no. 6, pp. 1273-1421, 2009.

[43] D. Aaron and C. Tsouris, "Separation of $\mathrm{CO}_{2}$ from flue gas: a review," Separation Science and Technology, vol. 40, no. 1-3, pp. 321-348, 2005.

[44] L. M. Robeson, "The upper bound revisited," Journal of Membrane Science, vol. 320, no. 1-2, pp. 390-398, 2008.

[45] C. J. Orme, M. K. Harrup, T. A. Luther et al., "Characterization of gas transport in selected rubbery amorphous polyphosphazene membranes," Journal of Membrane Science, vol. 186, no. 2, pp. 249-256, 2001.

[46] A. Brunetti, F. Scura, G. Barbieri, and E. Drioli, "Membrane technologies for $\mathrm{CO}_{2}$ separation," Journal of Membrane Science, vol. 359, no. 1-2, pp. 115-125, 2010.

[47] A. Mondal and B. Mandal, "Novel $\mathrm{CO}_{2}$-selective cross-linked poly(vinyl alcohol)/polyvinylpyrrolidone blend membrane 
containing amine carrier for $\mathrm{CO}_{2}-\mathrm{N}_{2}$ separation: Synthesis, characterization, and gas permeation study," Industrial \& Engineering Chemistry Research, vol. 53, no. 51, pp. 1973619746, 2014.

[48] C. S. K. Achoundong, N. Bhuwania, S. K. Burgess, O. Karvan, J. R. Johnson, and W. J. Koros, "Silane modification of cellulose acetate dense films as materials for acid gas removal," Macromolecules, vol. 46, no. 14, pp. 5584-5594, 2013.

[49] M. M. Khan, G. Bengtson, S. Neumann, M. M. Rahman, V. Abetza, and V. Filiz, "Synthesis, characterization and gas permeation properties of anthracene maleimide-based polymers of intrinsic microporosity," RSC Advances, vol. 4, no. 61, pp. 32148-32160, 2014.

[50] N. Du, G. P. Robertson, I. Pinnau, and M. D. Guiver, "Polymers of intrinsic microporosity with dinaphthyl and thianthrene segments," Macromolecules, vol. 43, no. 20, pp. 8580-8587, 2010.

[51] T. Emmler, K. Heinrich, D. Fritsch et al., "Free volume investigation of polymers of intrinsic microporosity (PIMs): PIM-1 and PIM1 copolymers incorporating ethanoanthracene units," Macromolecules, vol. 43, no. 14, pp. 60756084, 2010.

[52] B. S. Ghanem, N. B. McKeown, P. M. Budd, and D. Fritsch, "Polymers of intrinsic microporosity derived from bis(phenazyl) monomers," Macromolecules, vol. 41, no. 5, pp. $1640-$ 1646, 2008.

[53] P. M. Budd, N. B. McKeown, and D. Fritsch, "Polymers of intrinsic microporosity (PIMs): High free volume polymers for membrane applications," Macromolecular Symposia, vol. 245-246, pp. 403-405, 2006.

[54] A. E. Amooghin, H. Sanaeepur, M. Z. Pedram, M. Omidkhah, and A. Kargari, "New advances in polymeric membranes for $\mathrm{CO}_{2}$ separation," in Polymer Science: Research Advances, Practical Applications and Educational Aspects, A. MéndezVilas and A. Solano, Eds., pp. 354-368, 2016, http://www. formatex.info/polymerscience1/book/354-368.pdf.

[55] D. F. Sanders, Z. P. Smith, R. Guo et al., "Energy-efficient polymeric gas separation membranes for a sustainable future: a review," Polymer, vol. 54, no. 18, pp. 4729-4761, 2013.

[56] R. V. Siriwardane, M. S. Shen, and E. P. Fisher, "Adsorption of $\mathrm{CO}_{2}$ on zeolites at moderate temperatures," Energy \& Fuels, vol. 19, no. 3, pp. 1153-1159, 2005.

[57] J. E. Bauer, P. M. Williams, and E. R. M. Druffel, "Recovery of submilligram quantities of carbon dioxide from gas streams by molecular sieve for subsequent determination of isotopic (13C and 14C) natural abundances," Analytical Chemistry, vol. 64, no. 7, pp. 824-827, 1992.

[58] S. M. L. Hardie, M. H. Garnett, A. E. Fallick, A. P. Rowland, and N. J. Ostle, "Carbon dioxide capture using a zeolite molecular sieve sampling system for isotopic studies (13C and 14C) of respiration," Radiocarbon, vol. 47, no. 3, pp. 441-451, 2005.

[59] S. L. Jamesa, "Metal-organic frameworks," Chemical Society Reviews, vol. 32, no. 5, p. 276, 2003.

[60] A. R. Millward and O. M. Yaghi, "Metal-organic frameworks with exceptionally high capacity for storage of carbon dioxide at room temperature," Journal of the American Chemical Society, vol. 127, no. 51, pp. 17998-17999, 2005.

[61] J. R. Li, Y. Ma, M. C. McCarthy et al., "Carbon dioxide capture-related gas adsorption and separation in metalorganic frameworks," Coordination Chemistry Reviews, vol. 255, no. 15-16, pp. 1791-1823, 2011.

[62] K. S. Walton and R. Q. Snurr, "Applicability of the BET method for determining surface areas of microporous metal-organic frameworks," Journal of the American Chemical Society, vol. 129, no. 27, pp. 8552-8556, 2007.

[63] B. Arstad, H. Fjellvåg, K. O. Kongshaug, O. Swang, and R. Blom, "Amine functionalised metal organic frameworks (MOFs) as adsorbents for carbon dioxide," Adsorption, vol. 14, no. 6, pp. 755-762, 2008.

[64] R. Siriwardane, M. Shen, E. Fisher, and J. Losch, $\mathrm{CO}_{2}$ Capture Utilizing Solid Sorbents, U.S. Department of Energy National Energy Technology Laboratory, Pittsburgh, PA, USA, 2003, https://www.netl.doe.gov/publications/proceedings/04/carbonseq/039.pdf.

[65] A. U. Czaja, N. Trukhanb, and U. Müllerb, "Industrial applications of metal-organic frameworks," Chemical Society Reviews, vol. 38, no. 5, p. 1284, 2009.

[66] U. Mueller, M. Schubert, F. Teich, H. Puetter, K. Schierle-Arndta, and J. Pastréa, "Metal-organic frameworks-prospective industrial applications," ChemInform, vol. 37, no. 23, 2006.

[67] F. Merlin, H. Lombois, S. Joly, N. Lequeux, J. L. Halarya, and H. V. Damme, "Cement-polymer and clay-polymer nanoand meso-composites: spotting the difference," Journal of Materials Chemistry, vol. 12, no. 11, pp. 3308-3315, 2002.

[68] S. Chuah, Z. Pan, J. G. Sanjayan, C. M. Wang, and W. H. Duan, "Nano reinforced cement and concrete composites and new perspective from graphene oxide," Construction and Building Materials, vol. 73, pp. 113-124, 2014.

[69] A. E. Aleem, M. Heikal, and W. M. Morsi, "Hydration characteristic, thermal expansion and microstructure of cement containing nano-silica," Construction and Building Materials, vol. 59, pp. 151-160, 2014.

[70] Moscow IMET International, Nano Cements, June 2017, https:// www.globalimet.com/single-post/2015/05/10/Nano-cements.

[71] Marsel Yanovich Bickbau, "Method for producing nano-cement, and nano-cement," US Patent Publication No. EP 3006415 A1, 2016.

[72] https://nanotekmaterials.squarespace.com/advantages/, June 2017.

[73] M. S. Kirgiz, "Advancements in mechanical and physical properties for marble powder-cement composites strengthened by nanostructured graphite particles," Mechanics of Materials, vol. 92, pp. 223-234, 2016.

[74] http://www.nanotechmag.com/zenyatta-receives-funding-develop -nano-graphite-reinforced-cement/, 2017.

[75] R. F. Feldman and P. J. Sereda, "A model for hydrated Portland cement paste as deduced from sorption-length change and mechanical properties," Matériaux et Constructions, vol. 1, no. 6, pp. 509-520, 1968.

[76] J. Chen, S.-C. Kou, and C.-S. Poon, "Hydration and properties of nano- $\mathrm{TiO}_{2}$ blended cement composites," Cement and Concrete Composites, vol. 34, no. 5, pp. 642-649, 2012.

[77] B. Birgisson, A. K. Mukhopadhyay, G. Geary, M. Khan, and K. Sobolev, Nanotechnology in Concrete Materials: A Synopsis. Transportation Research Circular E-C170, Transportation Research Board, Washington, DC, USA, 2012.

[78] B. Birgisson, P. Taylor, J. Armaghani, and S. P. Shah, "American road map for research for nanotechnology-based concrete materials," Transportation Research Record: Journal of the Transportation Research Board, vol. 2142, pp. 130-137, 2010. 


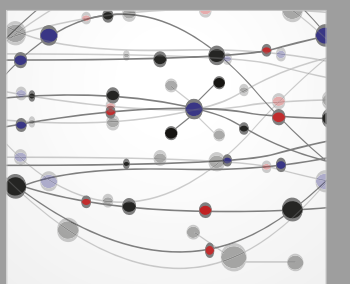

The Scientific World Journal
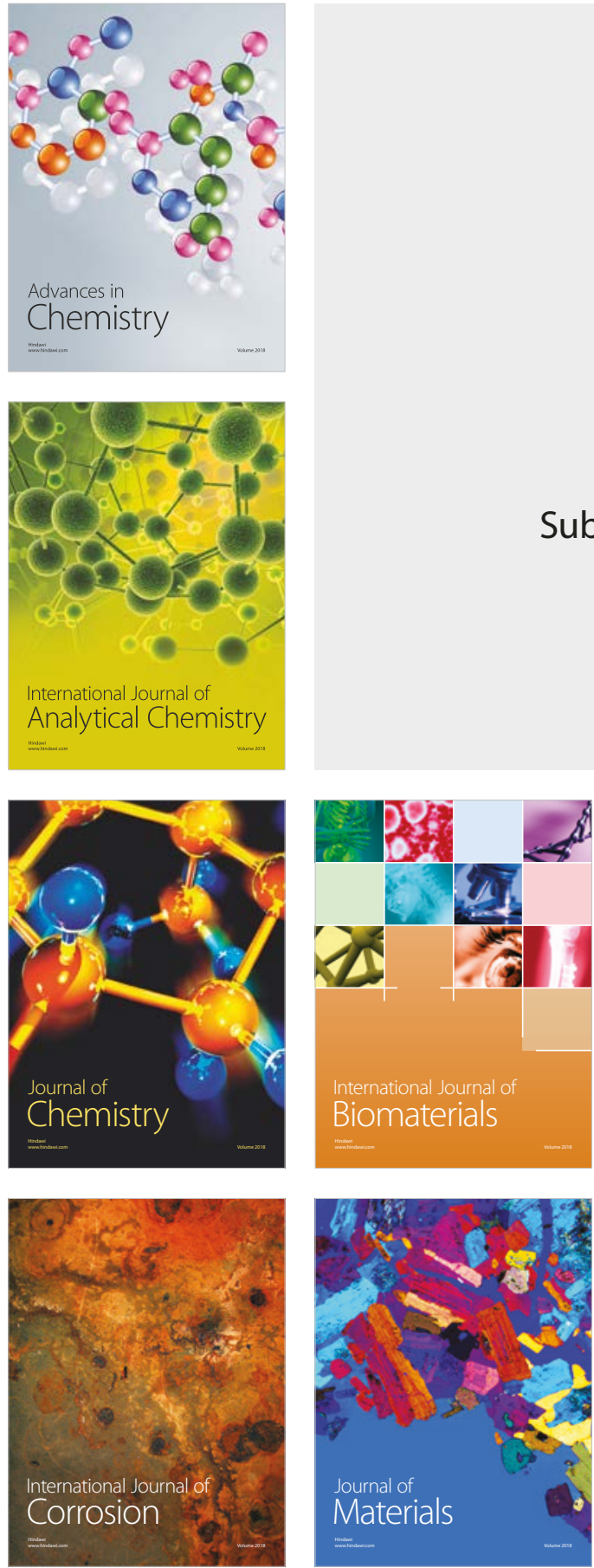

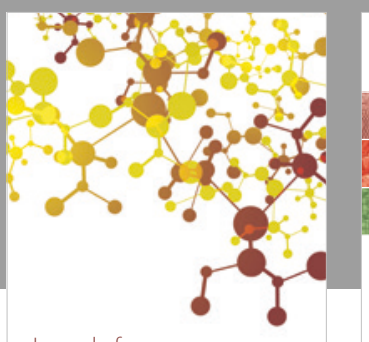

Journal of

Applied Chemistry
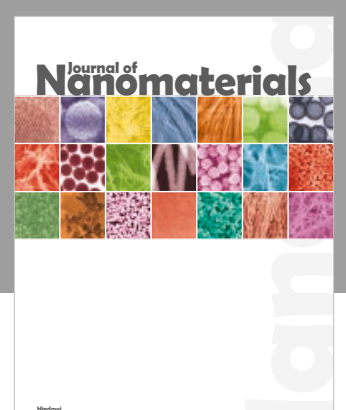

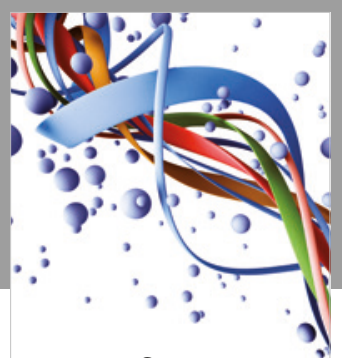

Scientifica

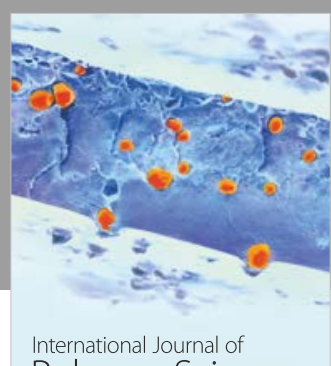

Polymer Science

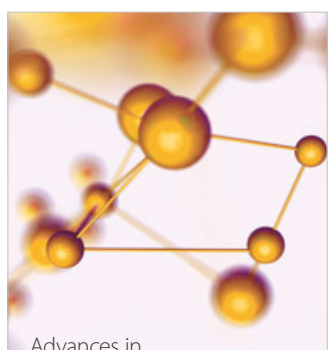

Physical Chemistry
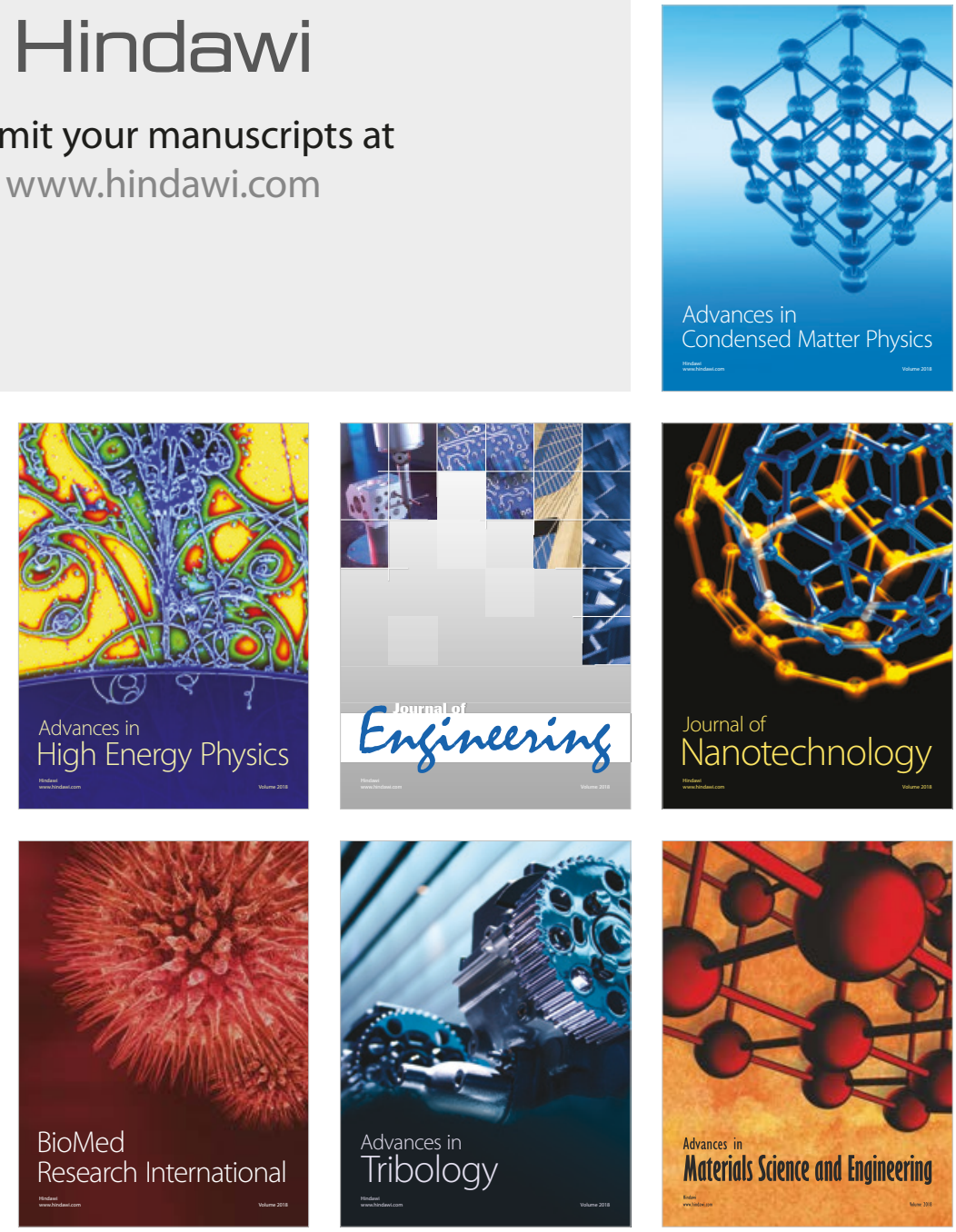